\title{
Trace element mobility in a polluted marine sediment after stabilisation with hydraulic binders
}

\author{
L. Saussaye ${ }^{\text {a }}$, H. Hamdoun ${ }^{\text {b }}$, L. Leleyter ${ }^{\text {b }}$, E. van Veen ${ }^{\text {c,d }}$, J. Coggan ${ }^{\text {c }}$, G. Rollinson ${ }^{c}$, W. Maherzi ${ }^{\text {e }}$, \\ M. Boutouil ${ }^{\mathrm{e}}$, F. Baraud ${ }^{\mathrm{b}, *}$

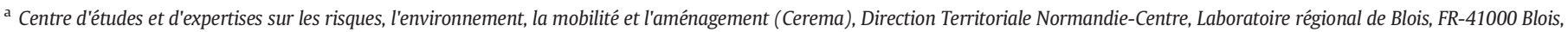 \\ France \\ b Normandie Univ, UNICAEN, Unité de Recherche Aliments Bioprocédés Toxicologie Environnements (UR ABTE) EA 4651, Bd Maréchal Juin, F-14032 Caen, France \\ c University of Exeter, Camborne School of Mines (CSM), College of Engineering, Mathematics and Physical Sciences (CEMPS), Penryn, Cornwall TR10 9EZ, UK \\ d University of Exeter, Environment and Sustainability Institute (ESI), Penryn, Cornwall TR10 9EZ, UK \\ e Ecole Supérieure d'Ingénierie et des Travaux de la Construction de Caen (ESITC Caen), F-14610 Epron, France
}

\section{A R T I C L E I N F O}

\section{Article history:}

Received 29 February 2016

Received in revised form 6 June 2016

Accepted 8 June 2016

Available online $\mathrm{xxxx}$

\section{Keywords:}

Contaminated sediment

Hydraulic binders

Mineralogy

Mobility study

Trace elements

\begin{abstract}
A B S T R A C T
The management of dredged marine sediment is an issue for many harbours, particularly when contaminant concentrations prevent disposal at sea. The stabilisation/solidification of the sediments with hydraulic binders for a use in road subgrade layer is a potential alternative solution. However, the environmental acceptability is not yet fully established. This paper presents the results of a case study to comprehensively determine the stabilisation of $\mathrm{As}, \mathrm{Cd}, \mathrm{Cr}, \mathrm{Cu}, \mathrm{Ni}, \mathrm{Pb}$ and $\mathrm{Zn}$. After demonstrating that stabilisation/solidification affects the microstructure of the sediment, a mobility study is realised (single, sequential and kinetic extractions). According to the regulatory/ technical guidelines the studied elements do not pose a risk to the environment. However, results from more complex mobility studies reveal that stabilisation in the short term is only effective for Ni while other elements are mobilised after treatment by at least one type of extraction. Stabilisation in the long term is not universally effective.
\end{abstract}

(c) 2016 Elsevier Ltd. All rights reserved.

\section{Introduction}

In Europe, the OSPAR (Oslo-Paris) Commission regulates dredging activities (OSPAR Commission, 2008). Signatory countries to the OSPAR Convention are required to establish national action values for contaminants in dredged material. In France, this was achieved by the GEODE (Groupe d'Etudes et d'Observations sur les Dragages et l'Environnement/Group of Studies and Observations on Dredgings and Environment) which established reference thresholds for disposal at sea. The OSPAR convention recommends that other management options be considered where the characteristics of the dredged material are such that sea disposal is not permitted. In France, this is connected to the waste legislation and must comply with a methodological guide (SETRA, 2011) (Service d'Etudes sur les Transports, les Routes et leurs

\footnotetext{
* Corresponding author at: Normandie Univ, UNICAEN, Unité de Recherche Aliments Bioprocédés Toxicologie Environnements (UR ABTE) EA 4651, Bd Maréchal Juin, F-14032 Caen, France.

E-mail addresses: lucile.saussaye@cerema.fr (L. Saussaye), hakim-hamdoun@hotmail.fr (H. Hamdoun), lydia.reinert@unicaen.fr (L. Leleyter) E.M.van-veen@exeter.ac.uk (E. van Veen), J.coggan@exeter.ac.uk (J. Coggan), G.rollinson@exeter.ac.uk (G. Rollinson), dir.recherche@esitc-caen.fr (M. Boutouil), fabienne.baraud@unicaen.fr (F. Baraud).
}

Aménagements/a French government technical agency that oversees road, transportation and infrastructure) for the use of alternative materials in roads. Both require analysis of certain substances in the water soluble fraction of waste materials.

The mineralogical and/or chemical speciation of chemical elements within the sediment and the potential remobilisation of those elements from the solid matrix are affected by the change in environmental conditions following dredging and subsequent treatment. Single, sequential and kinetic chemical extractions are widely used as tools to interpret the element mobility in sediments. One important environmental variable is $\mathrm{pH}$. A decrease in $\mathrm{pH}$ could be caused by acid rain, occurring either while the sediments undergo dehydration and storage prior to road construction, or in situ following road construction. A rise in $\mathrm{pH}$ will occur following the addition of hydraulic binders and/or lime during road construction. Single reagent extractions using e.g. $1 \mathrm{~mol} \cdot \mathrm{L}^{-1}$ $\mathrm{HCl}$ are recommended to predict element mobility in marine sediments under acid conditions (Doherty et al., 2000; Scouller et al., 2006; Leleyter et al., 2012), while NaOH can be used to predict element mobility under alkaline conditions (Hamdoun, 2013). Sequential extractions determine the geochemical distribution of the chemical elements, providing information on their affinity for different mineral phases (Ure et al., 1995; Leleyter and Probst, 1999). Kinetic extractions are used to 
investigate longer term element mobility. For example, the equilibrium time for all elements is reached in $24 \mathrm{~h}$ when EDTA is used as the extractant (Fangueiro et al., 2002; Cornu et al., 2004; Abi-Ghanem, 2008).

The dilution of contaminants in the sediment is not an acceptable treatment solution (SETRA, 2011). However, the addition of hydraulic binders during the stabilisation/solidification treatment is generally considered to reduce the mobility of elements (Bone et al., 2004; St Laurent et al., 2012). If this approach is taken, a water leach is required to establish the efficacy of contaminant immobilisation and highlight any remaining environmental risk of the material. Chatain et al. (2013) studied the mobility of $\mathrm{Cu}, \mathrm{Pb}$ and $\mathrm{Zn}$ in treated dredged sediment by performing various leaching tests. She reported that only $\mathrm{Zn}$ mobility was increased by a pH variation. However, she explained that the treatment could immobilise this element as (oxi)hydroxides and reduced the association to the reducible fraction.

This paper presents the results of a detailed and multidisciplinary case study that follows the treatment and stabilisation of a contaminated marine dredged sediment. The physical, chemical, microstructural and mineralogical characterisations of the raw sediment are first established along with the mobility of $\mathrm{As}, \mathrm{Cd}, \mathrm{Cr}, \mathrm{Cu}, \mathrm{Ni}, \mathrm{Pb}$ and $\mathrm{Zn}$ in the raw sediment. These elements are often present in dredged sediment and are targeted by GEODE thresholds and the SETRA methodological guide as they are of environmental concern. The acceptability of the treatment in terms of geotechnical and environmental parameters is then established.

The approach is therefore innovative with regard to the existing studies on reuse of sediment in civil engineering which focus only on the environmental or geotechnical aspects (Marot, 1994; Boutouil, 1998; Rey, 1999; Colin, 2003; Lemée, 2006; Agostini et al., 2007; Rekik, 2007; Lafhaj et al., 2008; Nguyen, 2008; Duan, 2008; Scordia et al., 2008; Tran, 2009; Brakni et al., 2009; Zentar et al., 2009; Agostini et al., 2010).

\section{Material and methods}

The sediment was dredged in June 2010 from the military port of Cherbourg, France. Approximately $600 \mathrm{~L}$ of dredged material was stored in several $70 \mathrm{~L}$ sealed plastic barrels.

\subsection{Sediment preparation and treatment}

\subsubsection{Preparation of the raw sediment}

The sediment initially contained a large amount of water (approximately $100 \%$ of the dry matter weight). Sediments were dehydrated in an oven at $40{ }^{\circ} \mathrm{C}$. Clumps formed during drying were removed by crushing and sieving to $2 \mathrm{~mm}$ producing a test material of $0 / 2$ dry sediment. Representative sub-samples were taken from this material for geochemical, mineralogical and geotechnical characterisation. The raw sediment was also characterised by loss of mass on ignition (LOI) (organic matter content measurement), particle size distribution and Atterberg limits. These parameters allow a classification according to the Unified Soil Classification System (USCS).

\subsubsection{Stabilisation and solidification treatment}

The raw sediment was treated with $3 \%$ of quicklime and $6 \%$ of cement CEMII/B 32.5R with respect to the dry mass of the mixture. After treatment, geochemical and microstructural analyses were undertaken on fragments of cylindrical samples of $50 \mathrm{~mm}$ in diameter by $50 \mathrm{~mm}$ in length, compacted at Optimal Moisture Content (OMC) and 96\% of the Maximal Dry Density (MDD). These samples are initially used to determine mechanical strengths evolution of the treated sediment. Indirect tensile strength (ITS, application of a stress until the splitting failure) of the treated sediment is measured according to standard EN 1328642 , on a press with a $50 \mathrm{kN}$ sensor. The standard Proctor optimum evolved from $19.5 \%$; $1.62 \mathrm{t} \cdot \mathrm{m}^{-3}$ before treatment to $20.4 \%$; $1.57 \mathrm{t} \cdot \mathrm{m}^{-3}$ after treatment. The MDD decrease is theoretically due to the flocculation induced by the addition of the quicklime (LCPCSETRA, 2000). Replicate samples were cured in a hermetically sealed mould at constant temperature $\left(20 \pm 2{ }^{\circ} \mathrm{C}\right)$ with an average relative humidity of $98 \%$. Microstructural and mineralogical analyses were performed on treated sediment after 90 days of hydration and physicochemical analysis after 180 days.

\subsection{Mineralogical and microstructural analysis by automated mineralogy}

Mineral identification was achieved using the Quantitative Evaluation of Mineralogy by Scanning Electron Microscopy (QEMSCAN®) technique for automated mineralogy. The technique is based on the point by point acquisition of energy dispersive spectra across a sample. Each spectrum is allocated to a specific mineralogy and sample mineralogy is inferred from the chemical spectra acquired (Rollinson et al., 2011) and false colour images allow the visual comparison of samples (van Veen et al., 2013a, 2013b). A review of the QEMSCAN® applications is given by Pirrie et al. (2009) and further details can be found in Gottlieb et al. (2000); Pirrie et al. (2004) and Pirrie and Rollinson (2011).

Samples were analysed on the QEMSCAN® 4300 system at the University of Exeter using particle mineralogical analysis (PMA) and field scan (FS) operating modes. Data collection was computer controlled using iMeasure software. Data were processed to produce a simplified mineral/phase list using iDiscover software. PMA operating mode systematically maps the composition of each discrete particle within the prepared sample providing quantitative data on mineralogy, particle grain size and shape. This was used to analyse both the raw sediment and solid residues following extraction with $\mathrm{HCl}$ (see Section 2.3). FS operating mode was used to map the monoliths (blocs or fragments) produced following sediment treatment after 90 days of hydration.

\subsection{Geochemical analysis and extraction of the raw and treated sediment}

The geochemical analysis focused on $\mathrm{As}, \mathrm{Cd}, \mathrm{Cr}, \mathrm{Cu}, \mathrm{Ni}, \mathrm{Pb}$ and $\mathrm{Zn}$. Total concentrations of these elements are required for assessment according to the GEODE thresholds values and can also be used to calculate the percentage of elements leached by the chemical extractions, thus estimating their operational mobility (Eq. (1)).

Mobilised X $(\%)=100 \times[\mathrm{X}]$ leached $/[\mathrm{X}]$ total

Total concentrations were determined by solubilising $0.2 \mathrm{~g}$ of dry sediment in aqua regia $\left(3.33 \mathrm{~mL}\right.$ of conc. $\mathrm{HNO}_{3}(68 \%)$ and $6.66 \mathrm{~mL}$ of conc. $\mathrm{HCl}(35 \%)$ ) using microwave digestion (Berghof speedwave MWS-2). The analytical quality of the data was controlled using certified reference material HR-1 (Canada Centre for Inland Waters National Laboratory for Environmental).

Single batch extractions were performed at room temperature with pure water, $1 \mathrm{~mol} \cdot \mathrm{L}^{-1} \mathrm{HCl}(\mathrm{pH}=0)$ and $0.1 \mathrm{~mol} \cdot \mathrm{L}^{-1} \mathrm{NaOH}(\mathrm{pH}=13)$. A liquid to solid (L:S) ratio of $10: 1$ was used in each extraction. Where pure water was used as the extractant, the mixture was shaken for $24 \mathrm{~h}$ following EN 12457-2 standard; for the extractions using $\mathrm{HCl}$ and $\mathrm{NaOH}$, the mixtures were shaken only for $1 \mathrm{~h}$ (Leleyter et al., 2012; Hamdoun, 2013).

Sequential extraction reveals the geochemical partitioning of the elements. Sequential extraction method described in Leleyter and Probst (1999) was chosen among several procedures because it was checked for selectivity, reproducibility and repeatability of the different steps and it was commonly used in literature (Bur et al., 2009; Cecchi et al., 2008; N'guessan et al., 2009; Salvarredy-Aranguren et al., 2008). The procedure dissolves selectively end efficiently all the chemical constituents of the sediment which can be affected by changes in physicochemical conditions (Leleyter and Probst, 1999; Leleyter and Baraud, 2005). So the successive extractions allowdefining chemical affinity of the elements in the following order: elements dissolved by water (F1) which 
correspond to water soluble salts, exchangeable elements (F2) adsorbed on permanent structural charges mainly present on clay minerals, elements bound to acido-soluble fraction (F3) or carbonate minerals, reducible fraction (F4) which represents manganese oxides, amorphous iron oxides and crystalline iron oxides and oxidisable fraction (F5) which represents sulfides and organic materials. These five fractions are the labile fraction of the sediment; the remaining solid fraction is the residual fraction.

The single and sequential extractions described above are based on a thermodynamic approach and are commonly used in mobility studies with soils and sediments. In kinetic extraction, an additional parameter of time is included in the search for the equilibrium of the mobilised element. Then, fast and slow metal mobilisation can be distinguished (Bordas and Bourg, 1998; Bermond et al., 2005). Fangueiro et al. (2005) assert that the two-compartment model has the advantage of separating the elements into three distinct categories; Q1: quickly mobilised, Q2: slowly mobilised and Q3: not mobilised. Kinetic extractions were performed using a solution of EDTA at $0.05 \mathrm{~mol} \cdot \mathrm{L}^{-1}$ with 13 contact times ranging from $15 \mathrm{~min}$ to $24 \mathrm{~h}$ and a L:S ratio of 10:1. EDTA is used as extractant because it is non-specific (only cations) and can therefore mobilise a large number of elements; it is also capable of extracting metal bound to organic matter, carbonate and Fe and Mn oxides providing good long-term prediction of metal bioaccessibility from these different sediment phases (Gismera et al. (2004); Labanowski et al. (2008)).

Three replicate extractions of each extraction procedure were undertaken. After filtration of the solid/liquid mixture at $0.45 \mu \mathrm{m}$, solutions were stored at $4{ }^{\circ} \mathrm{C}$ prior to analysis using Inductively Coupled Plasma-
Atomic Emission Spectrometry (ICP-AES) Varian Vista MPX (for operating conditions and quality criteria see Hamdoun (2013) and Hamdoun et al. (2015b)).

\section{Results and discussion}

\subsection{Characteristics of the raw sediment}

\subsubsection{Physical characteristics and mineralogy}

The sediment has an organic matter content (by loss of mass on ignition ( $\mathrm{LOI})$ ) of $7.6 \%$, a fine fraction $(<80 \mu \mathrm{m})$ of $87.0 \%$ and a clay activity ( $\mathrm{A}=$ plasticity index PI / percentage of the clay fraction) of 2.2. The sediment was classified as organic material with high plasticity $(\mathrm{OH})$ according to the Unified Soil Classification System (USCS), i.e. organic material with high plasticity. The QEMSCAN® analysis displayed graphically in Fig. 1 revealed that, quartz, carbonates, mica/illite, Fe Al silicates or feldspars were major phases in the raw sediment. This is consistent with the observations of Boutouil (1998); Colin (2003); Dubrulle et al. (2007); Rekik (2007) and Scordia et al. (2008). Furthermore, halite was observed which is typical of dehydrated marine sediments (salt present in sea water) and apatite which may be a constituent of fishbone or animal skeleton.

\subsubsection{Geochemical characteristics}

Table 1 reports the total concentrations of $\mathrm{As}, \mathrm{Cd}, \mathrm{Cr}, \mathrm{Cu}, \mathrm{Ni}, \mathrm{Pb}$ and $\mathrm{Zn}$ measured in the raw sediment as well as the French thresholds values (N1, N2) for disposal at sea. $\mathrm{As}, \mathrm{Cr}$ and $\mathrm{Ni}$ total concentrations were lower than the $\mathrm{N} 1$ level; however, $\mathrm{Cd}, \mathrm{Cu}$ and $\mathrm{Zn}$ total (a)

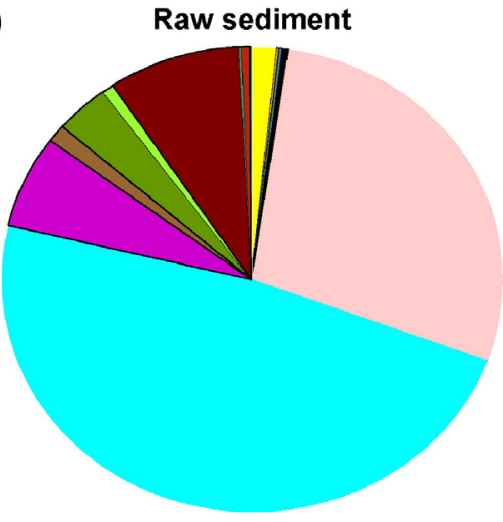

(b)

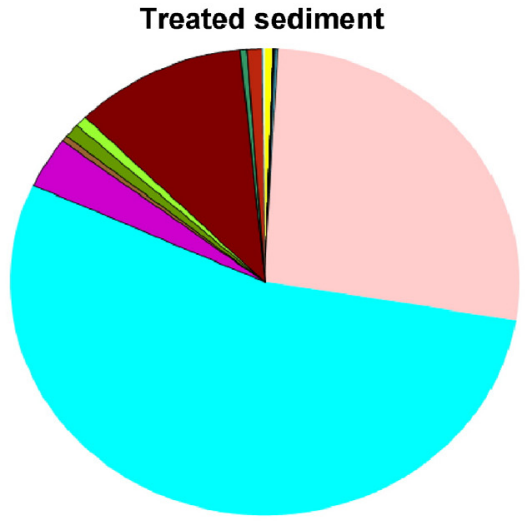

(c)

False color image of a monolith of treated sediment at 90 days

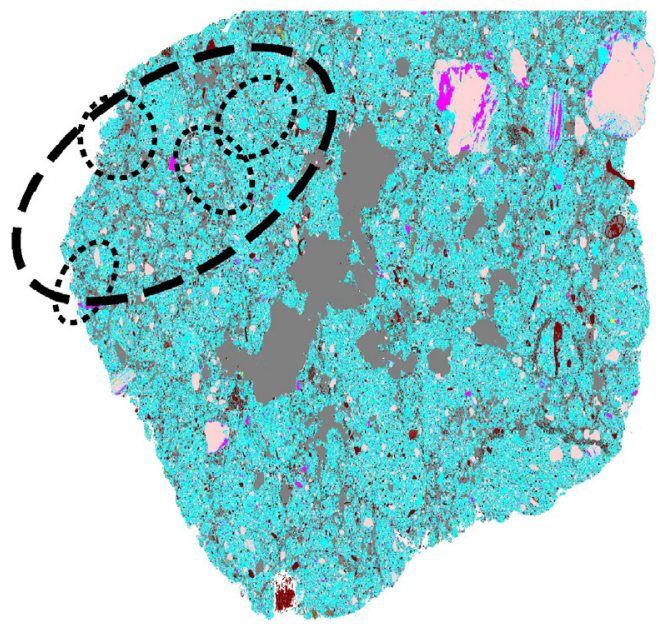

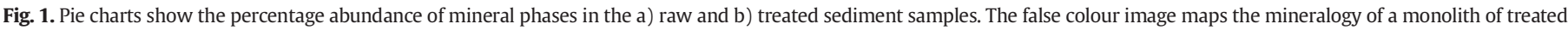

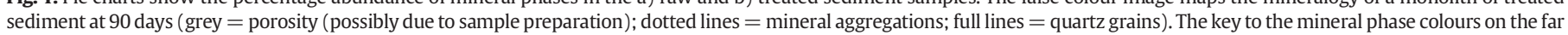
right applies to all three images. (For interpretation of the references to colour in this figure legend, the reader is referred to the web version of this article.) 
Table 1

Total element concentrations in the raw sediment and GEODE reference levels for disposal at sea (in $\mathrm{mg} \cdot \mathrm{kg}^{-1}$ of dry sediment, on the $<2 \mathrm{~mm}$ fraction of the sediment).

\begin{tabular}{ccccc}
\hline & \multicolumn{2}{c}{ Reference levels } & \multicolumn{2}{c}{ Marine dredged sediment } \\
Elements & $\mathrm{N}^{\mathrm{a}}$ & $\mathrm{N} 2^{\mathrm{a}}$ & Mean value & Standard deviation \\
\hline $\mathrm{As}$ & 25 & 50 & 17 & 2 \\
$\mathrm{Cd}$ & 1.2 & 2.4 & 1.8 & 0.1 \\
$\mathrm{Cr}$ & 90 & 180 & 28 & 1 \\
$\mathrm{Cu}$ & 45 & 90 & 59 & 1 \\
$\mathrm{Ni}$ & 37 & 74 & 14 & 1 \\
$\mathrm{~Pb}$ & 100 & 200 & 263 & 6 \\
$\mathrm{Zn}$ & 276 & 552 & 316 & 9 \\
\hline
\end{tabular}

aFrench GEODE levels N1 and N2 are defined by "arrêté of 14/06/2000"

value higher than the $\mathrm{N} 1$ level

value higher than the $\mathrm{N} 2$ level

concentrations were between the N1 and the N2 levels and the Pb total concentration exceeds the N2 level. The sediment would therefore be classified as unsuitable for disposal at sea without further investigation.

Element concentrations in the water soluble fraction and the percentage of the total concentration mobilised (when using the SETRA methodology) are reported for the raw sediment in Table 2. As, $\mathrm{Cd}, \mathrm{Cr}$, $\mathrm{Cu}, \mathrm{Ni}, \mathrm{Pb}$ and $\mathrm{Zn}$ concentrations measured in the water soluble fraction did not exceed the recommended thresholds.

The percentages of elements mobilised from the raw sediment by $\mathrm{HCl}$ and $\mathrm{NaOH}$ single extractions are also reported in Table 2. NaOH extraction simulates the $\mathrm{pH}$ rise (up to $\mathrm{pH} 12.4$ ) that occurs when hydraulic binder is added to the sediment and is therefore used to predict mobilisation of the elements during treatment with hydraulic binders. All the elements except $\mathrm{Cd}$ and $\mathrm{Cr}$ underwent more mobilisation (i.e. higher percentage values) with $\mathrm{NaOH}$ than with water. The percentages of $\mathrm{Cr}$ and $\mathrm{Cd}$ mobilised were negligible; percentages of $\mathrm{Cu}, \mathrm{Ni}, \mathrm{Pb}$ and $\mathrm{Zn}$ also remained quite low (2-7\%) but mobilisation of As was more significant (35\%).

More element mobilisation occurred with $\mathrm{HCl}$ than with water. The average mobility values were $<20 \%$ for $\mathrm{As}, \mathrm{Cd}, \mathrm{Cr}, \mathrm{Cu}$ and $\mathrm{Pb}$ but $>20 \%$ for $\mathrm{Ni}$ and $\mathrm{Zn}$.

Mobilisation of As during extraction was higher with $\mathrm{NaOH}(35 \%)$ than $\mathrm{HCl}(12 \%)$. The mobilisation of As under both basic and acidic conditions can be explained by its amphoteric nature (Matera et al., 2003). The mobilisation data for $\mathrm{Cd}, \mathrm{Cr}, \mathrm{Cu}, \mathrm{Ni}, \mathrm{Pb}$ and $\mathrm{Zn}$ indicated that that the risk of mobilisation may be lower in the raised $\mathrm{pH}$ environment following treatment with hydraulic binders than during landfill disposal, when the sediment could be subject to leaching events associated with acid rainfall and a decrease in $\mathrm{pH}$.

QEMSCAN $®$ analysis of the solid residue following $\mathrm{HCl}$ extraction, presented in Fig. 2, confirmed the dissolution of carbonates during $\mathrm{HCl}$ extraction. Of the major minerals, it is the carbonates and feldspars that are affected, which decreased by 8 to $<1 \%$ and 48 to $40 \%$ respectively. In contrast, mica/illite, Fe Al silicates, Al silicates increased by 6 to $10 \%, 3$ to $11 \%$ and 1 to $8 \%$ respectively. The extraction had no influence on the proportion of quartz determined.

The association of the elements with geochemical fractionations as determined by a five step sequential extraction is presented in Fig. 3. Only three elements had a significant acid-soluble fraction: As (19\%), $\mathrm{Ni}(10 \%)$ and $\mathrm{Zn}(9 \%)$. The affinity with the acid-soluble fraction of $\mathrm{Ni}$ and $\mathrm{Zn}$ was also detected by the single $\mathrm{HCl}$ extraction (Table 2) which would dissolve the acid-soluble fraction along with other (or parts of other) possible fractions such as the water soluble and exchangeable fraction. All the elements were located preferentially in the reducible fraction. The observed geochemical distribution is consistent with the literature where many references report on the chemical fractionation of the elements of interest. According to Belzile and Tessier (1989) and Raven et al. (1998) As is often found in the iron oxyhydroxides (hydrous iron oxide, goethite, hematite). $\mathrm{Cr}$ is known to be associated with organic matter and sulfides (Span, 1984) and has also been found to be associated with as oxyhydroxides (Azzaoui et al., 1998; Illou, 1999; Hamdoun, 2013).

$\mathrm{Cu}$ and $\mathrm{Zn}$ are chalcophile elements (Goldschmidt, 1954). In sediments these elements are associated with both the oxidisable fraction (Span, 1984; Ramos et al., 1994; Azzaoui et al., 1998; Pempkowiak et al., 1999; Baize and Tercé, 2002; Algan et al., 2004) and the reducible fraction (Rousseau et al., 2009; Leleyter et al., 2012; Hamdoun et al., 2015a). Generally Cd is not considered to be mobile in the sediment matrix (McLaughlin and Singh, 1999); however Baraud and Leleyter (2012) and Hamdoun et al. (2015a) have found it to be associated with oxidisable and reducible fractions. Ni is often presented as an element with a low mobility because it is bound with aluminosilicates (Span, 1984; Lopez-Sanchez et al., 1996; Algan et al., 2004). Pb has a generally high affinity for organic matter and carbonates (Town and Filella, 2002; Navarro et al., 2008). This affinity is supported by Leleyter et al. (2012) and Hamdoun et al. (2015a), who also report an affinity for the reducible fraction.

There was no obvious correlation between the element fractionation and the mineralogy of the raw sediment. For example, the presence of a small proportion of oxides ( $<1 \%$ vol.) did not indicate the importance of the reducible fraction (11 to 69\%). Ni and $\mathrm{Zn}$, the two metals the most mobilised by $\mathrm{HCl}$ extraction from raw sediment, which is assumed to attack the carbonates, were also the two metals for which a significant acid-soluble fraction was observed in sequential extraction.

The mobility of the elements obtained using a kinetic model is presented in Fig. 4. This model has two compartments; Q1 (quickly mobilised elements) and Q2 (slowly mobilised elements). Hamdoun et al. (2015a) previously defined the kinetics of mobilisation of these elements and determined the time corresponding to compartments Q1 and Q2. For As, $\mathrm{Cd}, \mathrm{Cr}, \mathrm{Cu}, \mathrm{Ni}, \mathrm{Pb}$ and $\mathrm{Zn}$, the contact time of the $\mathrm{Q} 1 \mathrm{com}$ partment is 45 to $60 \mathrm{~min}$ (short term) and for the Q2 compartment it is around $24 \mathrm{~h}$ (long term). Except for As, the mobility of the elements was

Table 2

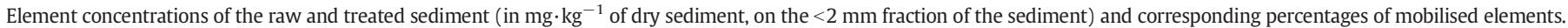

\begin{tabular}{|c|c|c|c|c|c|c|c|c|c|}
\hline \multirow[b]{3}{*}{ Elements } & \multirow{3}{*}{$\begin{array}{l}\text { Thresholds values } \\
\text { (SETRA, 2011) } \\
\text { (in } \mathrm{mg} \cdot \mathrm{kg}^{-1} \text { ) } \\
\text { (validation for a } \\
\text { use in road layer) }\end{array}$} & \multirow{3}{*}{$\begin{array}{l}\text { ICP-AES detection } \\
\text { limit (DL) } \\
\left(\text { in } \mathrm{mg} \cdot \mathrm{kg}^{-1}\right)\end{array}$} & \multicolumn{4}{|l|}{ Raw sediment } & \multicolumn{3}{|c|}{ Treated sediment, 180 days } \\
\hline & & & \multirow{2}{*}{$\begin{array}{l}\text { Total } \\
\text { concentration } \\
\left(\text { in } \mathrm{mg} \cdot \mathrm{kg}^{-1}\right)\end{array}$} & \multirow{2}{*}{$\begin{array}{l}\text { Water extraction } \\
\text { Mobilised element } \\
(\%)\end{array}$} & \multirow[t]{2}{*}{$\mathrm{HCl}$ extraction } & \multirow[t]{2}{*}{$\mathrm{NaOH}$ extraction } & \multirow{2}{*}{$\begin{array}{l}\text { Total } \\
\text { concentration } \\
\left(\text { in } \mathrm{mg} \cdot \mathrm{kg}^{-1}\right)\end{array}$} & \multirow{2}{*}{$\begin{array}{l}\text { Water extraction } \\
\text { Mobilised element } \\
(\%)\end{array}$} & \multirow{2}{*}{ HCl extraction } \\
\hline & & & & & & & & & \\
\hline As & 2 & $221 \cdot 10^{-3}$ & 17 & 0.6 & 12 & 35 & 15 & 2.7 & 79 \\
\hline $\mathrm{Cd}$ & 1 & $4 \cdot 10^{-3}$ & 2 & $<0.2$ & 0.2 & $<0.2$ & 2 & $<0.2$ & 65 \\
\hline $\mathrm{Cr}$ & 10 & $17 \cdot 10^{-3}$ & 28 & $<0.1$ & 11 & $<0.1$ & 26 & $<0.1$ & 80 \\
\hline $\mathrm{Cu}$ & 50 & $16 \cdot 10^{-3}$ & 59 & 0.5 & 15 & 5 & 55 & 1.3 & 71 \\
\hline $\mathrm{Ni}$ & 10 & $84 \cdot 10^{-3}$ & 14 & 0.6 & 21 & 7 & 11 & 2.7 & 19 \\
\hline $\mathrm{Pb}$ & 10 & $87 \cdot 10^{-3}$ & 263 & $<0.03$ & 10 & 2 & 289 & $<0.03$ & 19 \\
\hline Zn & 50 & $11 \cdot 10^{-3}$ & 316 & $<0.01$ & 39 & 5 & 345 & $<0.01$ & 57 \\
\hline
\end{tabular}


(a)

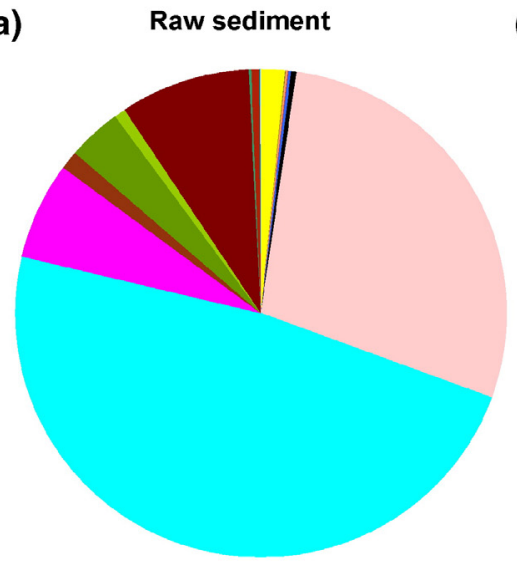

(b)

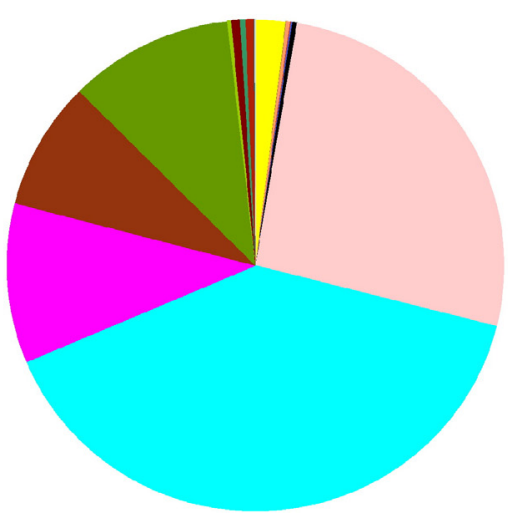

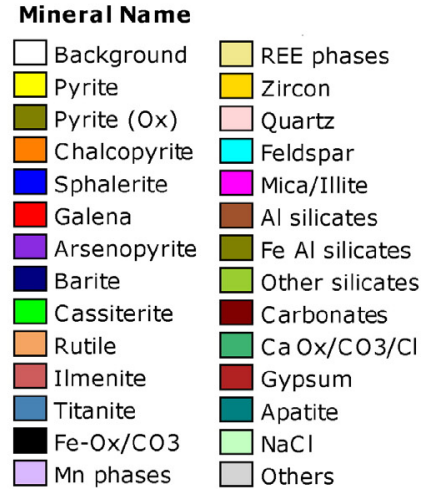

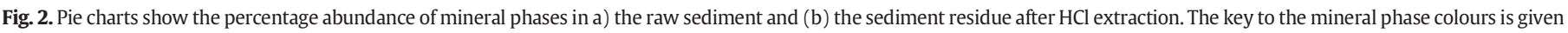
on the right. (For interpretation of the references to colour in this figure legend, the reader is referred to the web version of this article.)

the same in each compartment. As mobility was mainly associated with the Q2 compartment, highlighting the importance of long term risk assessment for this element.

\subsection{Geotechnical evolution of the treated sediment after 90 and 180 days curing}

Fig. 5 shows the evolution of the indirect tensile strength of the treated sediment with time. After 90 days, the ITS was $0.14 \mathrm{MPa}$; after 180 days, it reached $0.18 \mathrm{MPa}$. This represents an increase of 68 and $112 \%$ compared to the ITS measured at 7 days that is likely to be due to the reaction of the silicates in the matrix to form calcium silicate hydrates CSH, cementitious hydrates. These minerals bind the sediment grains improving its strength. Moreover, the presence of silica and alumina in the clay minerals of the fine sediment enable pozzolanic reactions, over several years. These will improve the long term mechanical strength of the material due to the formation of calcium silicate hydrate CSH or calcium aluminate hydrate CAH. It is advisable to verify if the mineralogical analyses allow supporting the microstructural evolution of the treated sediment. Then, if the solidification is proved by mechanical strengths improvement, the physicochemical analyses are led to validate or not a stabilisation of $\mathrm{Cd}, \mathrm{Cr}, \mathrm{Cu}, \mathrm{Ni}, \mathrm{Pb}$ and $\mathrm{Zn}$ by cementitious hydrates.

\subsection{Microstructural evolution of the treated sediment after 90 days curing}

A false colour image of the treated sediment after 90 days curing is presented in Fig. 1. It shows a very fine matrix mainly composed of quartz and feldspars. Quartz, mica/illite and carbonates were also present as coarse grains. The flocculation of the particles and the lumpy structure due to the addition of quicklime is observed in some areas (circled by black dotted lines).

Quartz, Fe Al silicates, Al silicates and mica/illite proportions are lower in the treated sediment than in the raw sediment. Cementitious hydrates are not specifically identified. Some of these hydrates can be amorphous, such as CSH. Others, such as portlandite (hydrated lime $\mathrm{CH}$ ) or CAH may be included in the carbonate and/or feldspar mineral phases, for which the percent mineral volume has increased in the treated sediment.

\subsection{Geotechnical and physicochemical evolution of the treated sediment after 180 days curing}

Total concentrations of each element in the treated sediment after 180 days curing were similar to those of the raw sediment (Table 2). The hydraulic binders contained very low concentrations of these elements (Saussaye, 2012); moreover, the mass of hydraulic binders added for the stabilisation and solidification of the sediment was low ( $9 \mathrm{~g}$ for $100 \mathrm{~g}$ of dry sediment). The addition of hydraulic binder was not therefore expected to significantly modify the total concentration of these elements in the treated sediment after 180 days of hydration.

Table 2 reports also the percentages of the total concentration mobilised in the water and $\mathrm{HCl}$ soluble fractions. In the water soluble fraction, higher percentage mobilisation values were observed for As, $\mathrm{Cu}$ and $\mathrm{Ni}$ after treatment compared with the raw sediment. Nevertheless, mobilisation remained weak ( $<1 \%$ for the raw sediment; $<3 \%$ for

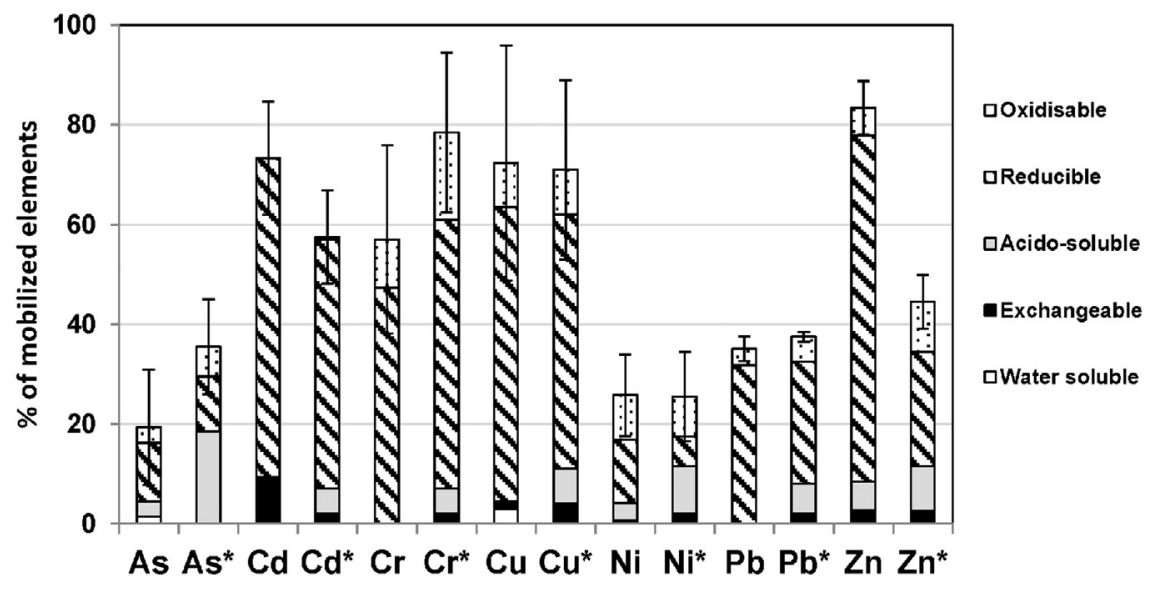

Fig. 3. Geochemical fractionation of the elements in the raw and treated $\left(^{*}\right)$ sediment. 


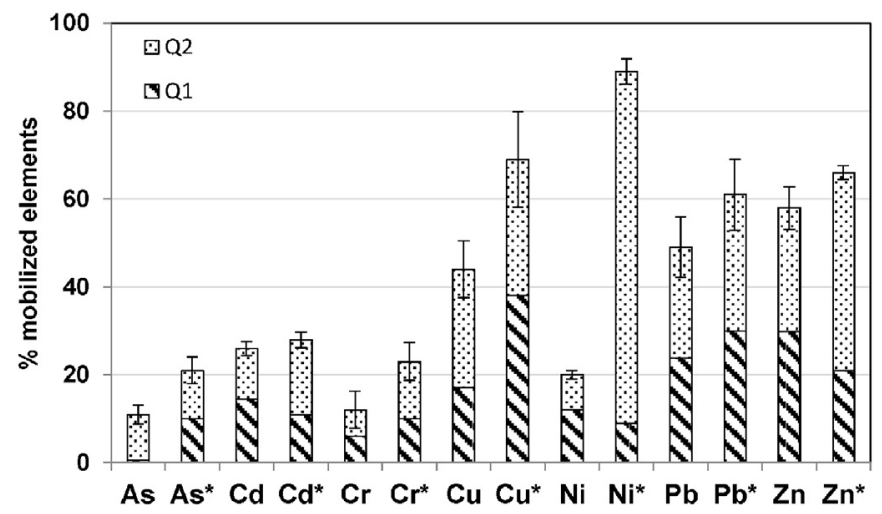

Fig. 4. Kinetic distribution of elements in the raw and treated $\left({ }^{*}\right)$ sediment.

the treated sediment), validating the use of the sediment in subgrade layer.

A decrease in element mobility can be explained by a loss of volatile and mobile elements during the exothermic hydration of the hydraulic binders, a change in environmental conditions ( $\mathrm{pH} \approx 12.4$ after treatment) or the immobilisation of elements in the cementitious hydrates by "encapsulation". An increase in element mobility could be associated with an embrittlement of the sediment matrix due to, for example, a rise in $\mathrm{pH}$.

Except for $\mathrm{Ni}, \mathrm{HCl}$ mobility of the elements significantly increased after treatment. This could be due to the solubility in acidic pH of cement hydrates which may have formed to include the elements of interest during treatment.

The geochemical fractionation of elements is presented in Fig. 3. For all the elements, except As and $\mathrm{Cr}$, the treatment with hydraulic binders tended to immobilise the elements, as the total labile fraction (sum of F1 to F5) remained unchanged or decreased after treatment. For As, the labile fraction increases from 19 to $36 \%$. This may be due a change in speciation (due to the amphoteric nature of As) induced by the treatment resulting in the association of As with a new acid-soluble compound, thus increasing the total mobility of As. The variation observed for $\mathrm{Cr}$ (57\% to $79 \%$ ) is more difficult to explain. For all the elements of interest, the treatment induced an increase in the acid-soluble fraction in sequential extraction. This may be correlated with the increase in carbonates detected in the treated sediments after 90 days curing by QEMSCAN® analysis. However, with the exception of As and Ni, mobility was predominantly associated with the reducible fraction F4.

The overall mobility (Q1 + Q2) was increased by the treatment for all the elements (Fig. 4). This increase is partly due to an increase in the quickly mobilised (Q1) compartment for $\mathrm{As}, \mathrm{Cr}, \mathrm{Cu}$ and $\mathrm{Pb}$ which became more easily mobilised by EDTA after treatment. However, the

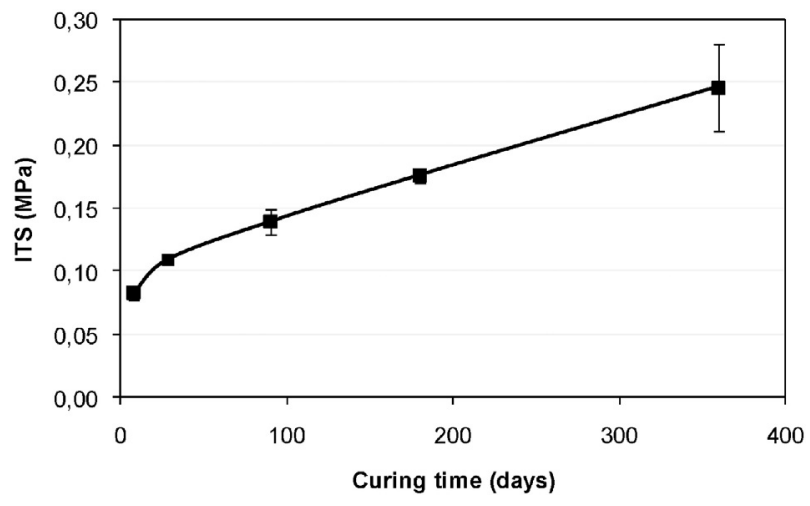

Fig. 5. Indirect tensile strength evolution of the treated sediment.
Q1 compartment was reduced for $\mathrm{Cd}$, Ni and $\mathrm{Zn}$ after treatment, suggesting a stabilisation of these elements in the short term.

The Q2 compartment was more important after treatment for all the elements but particularly for $\mathrm{Ni}$ and $\mathrm{Zn}$ suggesting that a consideration of the long term risk is necessary. Further analysis, after a longer curing period, should be undertaken to determine the evolution of the stabilisation processes. The results from kinetic testing confirmed the short term stabilisation of Ni. However the mobility of As and $\mathrm{Cr}$ was shown to increase in both the long and short term.

\section{Conclusions}

To promote the productive use of marine dredged sediments in road works, it is necessary to understand their physical, mineralogical, chemical and mechanical characteristics. This paper presents the results of these analyses for sediment sampled from a single port before and after stabilisation treatment:

- the sediment was a fine, moderately organic and its clay activity was important, classified as $\mathrm{OH}$ according to the USCS; mineralogical analyses revealed the presence of quartz, carbonates, feldspars, mica/illite and Fe Al silicates.

- the sediment was not suitable for disposal at sea according to total concentrations of metals but classified as environmentally acceptable for use in road subgrade layer according to standard technical guidelines based on pure water extraction.

- in alkaline environment, As, $\mathrm{Cu}$ and $\mathrm{Ni}$ mobilisation from the sediment is more important than in water; in an acid environment, carbonates in the matrix could be attacked and mobilise elements associated with the acid-soluble fraction.

- during long term exposure of the sediment to EDTA, similar percentages of the elements were associated with the slowly (Q2) and the quickly mobilised (Q1) compartments, except for As for which Q2 is higher than Q1. This shows the importance of considering the long term risk of mobilisation of these elements.

- treatment with $3 \%$ of quicklime and $6 \%$ of cement CEMII/B 32.5R improved the indirect tensile strength of the sediment which then increased with time; microstructural and mineralogical analyses show an increase in the percentage volume of carbonates and feldspars and flocculation of the sediment particles due to the addition of quicklime.

- after 180 days curing, the total concentrations of the elements in the treated sediment were similar to those in the raw sediment.

- mobility of the elements associated with the acid-soluble fraction, i.e. carbonates, had increased; $\mathrm{As}, \mathrm{Cd}, \mathrm{Cr}, \mathrm{Cu}, \mathrm{Ni}, \mathrm{Pb}$ and $\mathrm{Zn}$ were found to be mainly associated with the reducible fraction.

- mobility increase of these elements with time in the treated sediments is due to the increase in the Q2 compartment, leading to an increase in overall mobility (Q1 + Q2) with time.

So, in the case of this specific sediment, the $\mathrm{HCl}$, sequential and kinetic extractions all show that As and $\mathrm{Cr}$ do not appear stabilised after treatment with hydraulic binders and that the stabilisation of $\mathrm{Ni}$ is effective only in the short term.

These conclusions were reached for one sediment, one formulation of hydraulic binder, and one timescale. Future work should focus on studying other sediments, with different mineral, chemical and physical characteristics. It would also be appropriate to consider the behaviour of the material at different curing times in order to enhance understanding of the environmental impact of stabilisation and solidification treatment.

\section{Acknowledgements}

The authors thank the LASEM (Laboratoire d'Analyses de Surveillance et d'Expertise de la Marine) of Cherbourg for the dredging 
operation in the military port; Lhoist and Lafarge for their technical and scientifical supports; Europe, European Regional Development Fund (ERDF), Interreg IVA and Regional Council of Basse-Normandie for their financial support to the SETARMS project.

\section{References}

Abi-Ghanem, C., 2008. Spéciation des trois éléments traces $\mathrm{Hg}$, Pb et $\mathrm{Cd}$ dans les sédiments marins des zones côtières libannaises (Ph.D. Dissertation) Institut des Sciences et Industries du Vivant et de l'Environnement, Liban.

Agostini, F., Davy, C.A., Skoczylas, F., Dubois, T., 2010. Effect of microstructure and curing conditions upon the performance of a mortar added with Treated Sediment Aggregates (TSA). Cem. Concr. Res. 40, 1609-1619.

Agostini, F., Skoczylas, F., Lafhaj, Z., 2007. About a possible valorisation in cementitious materials of polluted sediments after treatment. Cem. Concr. Compos. 29, 270-278.

Algan, O., Balkis, N., Namikcagatay, M., Sari, E., 2004. The sources of metal contents in the shelf sediments from the Marmara Sea, Turkey. Environ. Geol. 46, 932-950.

Azzaoui, S., El Hanbali, M., Ben Mohammadi, A., 1998. Fractionnement chimique du chrome, cuivre et zinc dans les dépôts alluviaux de l'ouest Sebou (Khmiss Hamria, Fes). Afr. Geosci. Rev. 5, 123-127.

Baize, D., Tercé, M., 2002. Les éléments traces métalliques dans les sols: approches fonctionnelles et spatiales. Editions INRA, Paris.

Baraud, F., Leleyter, L., 2012. Prediction of phytoavailability of trace metals to plants: comparison between chemical extractions and soil-grown radish. Geosciences 344 385-395.

Belzile, N., Tessier, A., 1989. Interactions between arsenic and iron oxyhydroxides in lacustrine sediments. Geochem. Cosmochim. Acta 54, 103-109.

Bermond, A., Varrault, G., Sappin-Didier, V., Mench, M., 2005. A kinetic approach to predict soil trace metal bioavailability: preliminary results. Plant Soil 275, 21-29.

Bone, B.D., Barmard, L.H., Hills, C.D., 2004. Guidance on the Use of Stabilisation/Solidification for the Treatment of Contaminated Soil. Environment Agency.

Bordas, F., Bourg, A.C.M., 1998. Effect of complexing agents (EDTA and ATMP) on the remobilization of heavy metals from polluted river sediment. Aquat. Geochem. 4 201-214.

Boutouil, M., 1998. Traitement des vases de dragage par stabilisation/solidification à base de ciment et additifs (Ph.D. Dissertation) University of Le Havre, France.

Brakni, S., Abriak, N.E., Hequette, A., 2009. Formulation of artificial aggregates from dredged harbour sediments for coastline stabilization. Environ. Technol. 30, 849-854.

Bur, T., Probst, J.L., N'guessan, M., Probst, A., 2009. Distribution and origin of lead in stream sediments from small agricultural catchments draining Miocene molassic deposits (SW France). Appl. Geochem. 24, 1324-1338.

Cecchi, M., Dumat, C., Alric, A., Felix-Faure, B., Pradere, P., Guiresse, M., 2008. Multimeta contamination of a calcic cambisol by fallout from a lead-recycling plant. Geoderma $144,287-298$

Chatain, V., Benzaazoua, M., Loustau Cazalet, M., Bouzahzah, H., Delolme, C., Gautier, M., Blanc, D., de Brauer, C., 2013. Mineralogical study and leaching behavior of a stabilized harbor sediment with hydraulic binder. Environ. Sci. Pollut. Res. Int. 20, 51-59.

Colin, D., 2003. Valorisation de sédiments fins de dragage en technique routière (Ph.D. Dissertation) University of Caen Basse-Normandie, France.

Cornu, S., Montagne, D., Conil, P., 2004. Comparaison d'extractions séquentielles et cinétiques pour la spéciation de As dans des sols sableux contaminés. Geosciences 336, 1007-1015.

Doherty, G.B., Brunskill, G.J., Ridd, M.J., 2000. Natural and enhanced concentrations of trace metals in sediments of Cleveland Bay, Great Barrier Reef Lagoon, Australia. Mar. Pollut. Bull. 41, 337-344.

Duan, Z., 2008. Caractérisation, stabilisation et solidification de sédiments marins (Ph.D. Dissertation) University of Caen Basse-Normandie, France.

Dubrulle, C., Lesueur, P., Boust, D., Dugué, O., Poupinet, N., Lafite, R., 2007. Source discrimination of fine-grained deposits occurring on marine beaches: the Calvados beaches (eastern Bay of the Seine, France). Estuar. Coast. Shelf Sci. 72, 138-154.

Fangueiro, D., Bermond, A., Santos, E., Carapuça, H., Duarte, A., 2002. Heavy metal mobility assessment in sediments based on a kinetic approach of the EDTA extraction: search for optimal experimental conditions. Anal. Chim. Acta 459, 245-256.

Fangueiro, D., Bermond, A., Santos, E., Carapuça, H., Duarte, A., 2005. Kinetic approach to heavy metal mobilization assessment in sediments: choose of kinetic equations and models to achieve maximum information. Talanta 66, 844-857.

Gismera, M.J., Lacal, J., Da Silva, P., Garćia, R., Sevilla, M.T., Procopio, J.R., 2004. Study of metal fractionation in river sediments. A comparison between kinetic and sequentia extraction procedures. Environ. Pollut. 127, 175-182.

Goldschmidt, V.M., 1954. Geochemistry. Oxford University Press, London.

Gottlieb, P., Wilkie, G., Sutherland, D., Ho-Tun, E., Suthers, S., Perera, K., Jenkins, B. Spencer, S., Butcher, A., Rayner, J., 2000. Using quantitative electron microscopy for process mineralogy application. J. Miner. Met. Mater. Soc. 52, 24-25.

Hamdoun, H., 2013. Valorisation de sédiments de dragage en techniques routières et acceptabilité environnementale: caractérisation globale et études de mobilités d'éléments métalliques par extractions simples, séquentielles et cinétiques. Cas de sédiments de la Manche dans le cadre du projet SETARMS (Ph.D. Dissertation) University of Caen Basse-Normandie, France.

Hamdoun, H., Leleyter, L., Van-Veen, E., Coggan, J., Basset, B., Lemoine, M., Baraud, F., 2015b. Comparison of three procedures (single, sequential and kinetic extractions) for mobility assessment of $\mathrm{Cu}, \mathrm{Pb}$ and $\mathrm{Zn}$ in harbour sediments. Geosciences 347, 94-102.

Hamdoun, H., Van-Veen, E., Basset, B., Lemoine, M., Coggan, J., Leleyter, L., Baraud, F., 2015a. Characterization of harbor sediments from the English Channel: assessment of heavy metal enrichment, biological effect and mobility. Mar. Pollut. Bull. 90, 273-280.
Illou, S., 1999. Impact des rejets telluriques d'origines domestiques et industrielles sur les environnements côtiers: cas du littoral nord de la ville de Sfax (Tunisie) (Ph.D. Dissertation) University Tunis II - FST, Tunisie.

Labanowski, J., Fernandez, A., Bermond, A., Cambier, P., Lamy, I., Van Oort, F.C., 2008. EDTA vs citrate kinetic extractions to assess mobilization of trace metals ( $\mathrm{Zn}, \mathrm{Pb}, \mathrm{Cd}$ and $\mathrm{Cu}$ ) in metal contaminated soils. Environ. Pollut. 59, 693-701.

Lafhaj, Z., Samara, M., Agostini, F., Boucard, L., Skoczylas, F., Depelsenaire, G., 2008. Polluted river sediments from the North region of France: treatment with Novosol ${ }^{\circledR}$ process and valorization in clay bricks. Constr. Build. Mater. 22, 755-762.

LCPC-SETRA, 2000. Traitement des sols à la chaux et/ou aux liants hydrauliques Terrassement et couche de forme (GTS.

Leleyter, L., Baraud, F., 2005. Évaluation de la mobilité des métaux dans les sédiments fluviaux du bassin de la Vire (Normandie, France) par extractions simples ou séquentielles. Geosci. 337, 571-579.

Leleyter, L., Probst, J.L., 1999. A new sequential extraction procedure for the speciation of particulate trace elements in river sediments. Int. J. Environ. Anal. Chem. 73, 109-128.

Leleyter, L., Rousseau, C., Biree, L., Baraud, F., 2012. Comparison of EDTA, HCl and sequential extraction procedures, for selected metals $(\mathrm{Cu}, \mathrm{Mn}, \mathrm{Pb}, \mathrm{Zn})$, in soils, riverine and marine sediments. J. Geochem. Explor. 116, 51-59.

Lemée, F., 2006. Traitement par alcali activation de sédiments fins marins non contaminés et à faible teneur en eau - Mise au point d'un procédé de stabilisation (Ph.D. Dissertation) UCBN - ESITC Caen, France.

Lopez-Sanchez, J.F., Rubio, R., Samitier, C., Rauret, G., 1996. Trace metal partitioning in marine sediments and sludges deposited of the coast of Barcelona (Spain). Water Res. 30, 153-159.

Marot, F., 1994. Caractérisation et traitement des boues portuaires (MS) University of Le Havre, France.

Matera, V., Le Hécho, I., Laboudigue, A., Thomas, P., Tellier, S., Astruc, M., 2003. A methodological approach for the identification of arsenic bearing phases in polluted soils. Environ. Pollut. 126, 51-64.

McLaughlin, M.J., Singh, B.R.E., 1999. Cadmium in Soils and Plants (Developments in Plant and Soil Sciences). Kluwer Academic Publishers, Dordrecht, The Netherlands.

Navarro, M.C., Pérez-Sirvent, C., Martínez-Sánchez, M.J., Vidal, J., Tovar, P.J., Bech, J., 2008. Abandoned mine sites as a source of contamination by heavy metals: a case study in a semi-arid zone. J. Geochem. Explor. 96, 183-193.

N'guessan, Y.M., Probst, J.L., Bur, T., Probst, A., 2009. Trace elements in stream bed sediments from agricultural catchments (Gascogne region, S-W France): where do they come from? Sci. Total Environ. 407, 2939-2952.

Nguyen, T., 2008. Valorisation des sédiments de dragage traités par le procédé Novosol ® dans des matériaux d'assise de chaussée. Comportement mécanique et environnemental (Ph.D. Dissertation) Université Paul Sabatier, Toulouse, France.

OSPAR Commission, 2008. Overview of Contracting Parties' National Action Levels for Dredged Material.

Pempkowiak, J., Sikora, A., Biernacka, E., 1999. Specification of heavy metals in marine sediments, their bioaccumulation by mussel. Chemosphere 39, 313-321.

Pirrie, D., Rollinson, G., 2011. Unlocking the applications of automated mineral analysis. Geol. Today 27, 235-244.

Pirrie, D., Butcher, A.R., Power, M.R., Gottlieb, P., Miller, G.L., 2004. Rapid quantitative mineral and phase analysis using automated scanning electron microscopy (QEMSCAN $\left.{ }^{\circledR}\right)$; potential applications in forensic geoscience. In: Pye, K., Croft, D.J. (Eds.), Forensic Geoscience, Principles, Techniques and Applications 232. Geological Society Special Publication, London.

Pirrie, D., Rollinson, G., Power, M.R., 2009. Role of automated mineral analysis in the characterisation of mining-related contaminated land. Geosci. SW Engl. 12, 162-170.

Ramos, L., Remendez, L.M., Gonzalez, M.J., 1994. Sequential fractionation of copper, lead, cadmium and zinc in soils from or near Donana national park. J. Environ. Qual. 23, $50-57$

Raven, P.J., Boon, P.J., Dawson, F.H., Ferguson, A.J.D., 1998. Towards an integrated approach to classifying and evaluating rivers in the UK. Aquat. Conserv. Mar. Freshwat. Ecosyst. 8, 383-393.

Rekik, B., 2007. Propriétés géotechniques des sédiments de dragage traités au ciment (Ph.D. Dissertation) UCBN - ESITC Caen, France.

Rey, F., 1999. Etude physico-mécanique et environnementale du composite vase-chaux et additifs (Ph.D. Dissertation) University of Caen Basse-Normandie, France.

Rollinson, G., Andersen, J., Stickland, R.J., Boni, M., Fairhurst, R., 2011. Characterisation of non-sulphide zinc deposits using QEMSCAN®. Miner. Eng. 24, 778-787.

Rousseau, C., Baraud, F., Leleyter, L., Gil, O., 2009. Cathodic protection by zinc sacrificial anodes: impact on marine sediment metallic contamination. J. Hazard. Mater. 167, 953-958.

Salvarredy-Aranguren, M.M., Probst, A., Roulet, M., Isaure, M.P., 2008. Contamination of surface waters by mining wastes in the Milluni Valley (Cordillera Real, Bolivia): mineralogical and hydrological influences. Appl. Geochem. 23, 1299-1324.

Saussaye, L., 2012. Traitement des sols: aspects géotechniques et physico-chimiques des perturbations de la solidification (Ph.D. Dissertation) ESITC Caen-UCBN, France.

Scordia, P.Y., Lafhaj, Z., Skoczylas, F., Mongouin, T., 2008. Characterization and valorization of polluted and treated river sediments in road. Eur. J. Environ. Civil Eng. 7, 451-469.

Scouller, R.C., Snape, I., Stark, J., Gore, D.B., 2006. Evaluation of geochemical methods for discrimination of metal contamination in Antartic marine sediments: a case study from Casey Station. Chemosphere 65, 294-309.

SETRA, 2011. Guide d'acceptabilité des matériaux alternatifs en technique routière - Evaluation environnementale.

Span, D., 1984. Etude par fractionnement chimique de la distribution des métaux traces dans les sédiments marins récents: le Delta du Rhône, les golfes de St-Raphaël et de Cannes-La Napoule Ph.D. Dissertation University Pierre et Marie Curie, Paris VI, France. 
St Laurent, S., Burelle, S., Ouellette, H., 2012. Lignes directrices sur la gestion des matières résiduelles et des sols contaminés traités par stabilisation et solidification, Québec, Ministère du Développement durable, de l'Environnement et des Parcs.

Town, R.M., Filella, M., 2002. Crucial role of the detection window in metal ion speciation analysis in aquatic systems: the interplay of thermodynamic and kinetic factors as exemplified by nickel and cobalt. Anal. Chem. Acta 466, 285-293.

Tran, N.T., 2009. Valorisation de sédiments marins et fluviaux en technique routière (Ph.D. Dissertation) Douai School of Mines, France.

Ure, A.M., Davidson, C.M., Thomas, R.P., 1995. Single and sequential extraction schemes for trace metals speciation in soil and sediment. In: Quevauviller, P., Maier, E.A.,
Griepink, B. (Eds.), Quality Assurance for Environmental Analysis (BCR). Elsevier (Eds.).

van Veen, E., Andersen, J., Coggan, J., 2013a. Characterisation of dredged harbour sediment using automated mineralogy. GESeD Congress. Caen, France, 10-12 April.

van Veen, E., Hamdoun, H., Leleyter, L., Baraud, F., Rollinson, G., Andersen, J., Coggan, J. 2013b. What does the residual fraction look like? Automated mineralogy after three different single leach extractions. SETARMS Final Seminar. Saint-Brieuc, France 19 September.

Zentar, R., Abriak, N.E., Dubois, V., 2009. Effects of salts and organic matter on Atterberg limits of dredged marine sediments. Appl. Clay Sci. 42, 391-397. 